Journal of

Strategic Management

(JSM)

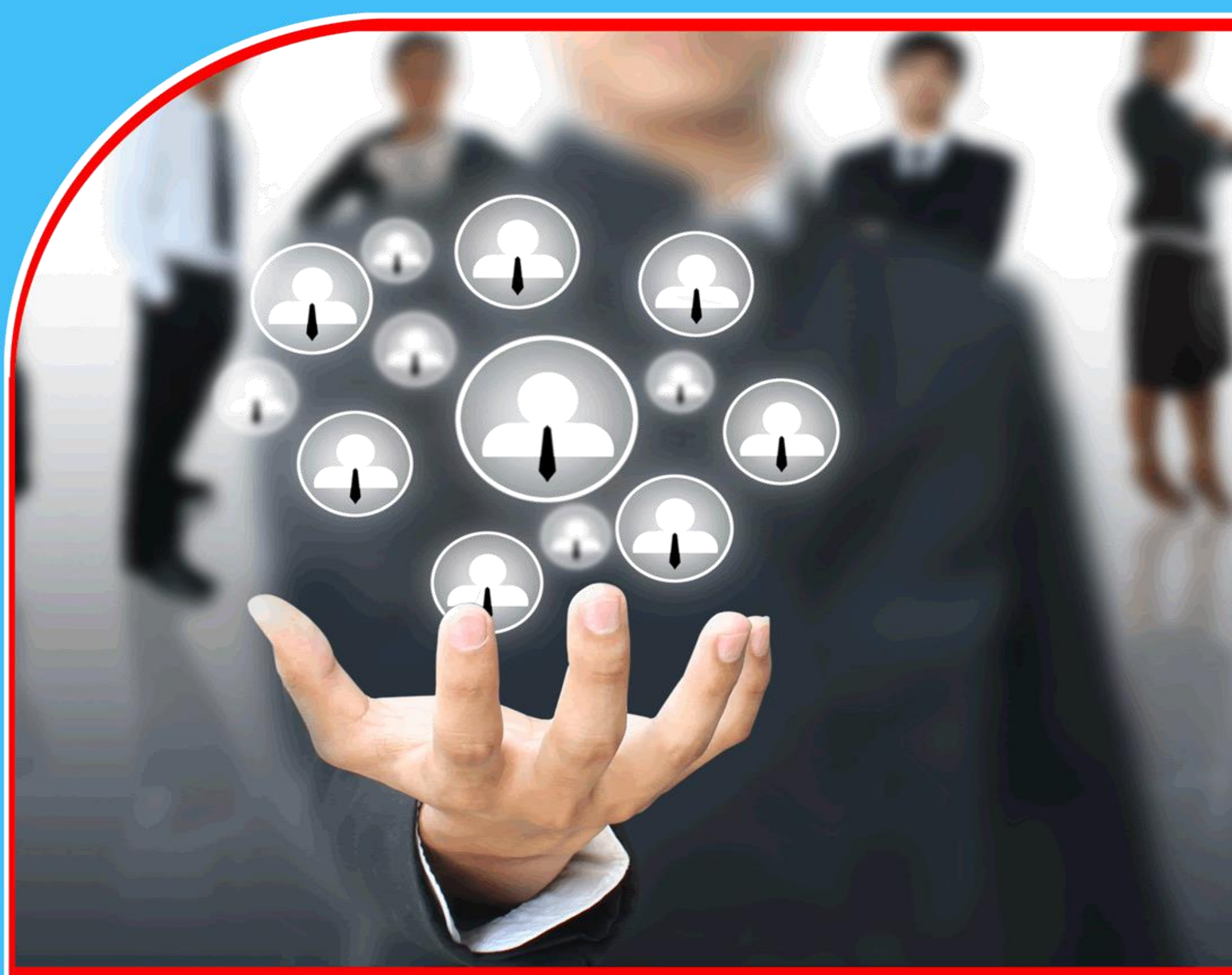

SUSTAINABLE STRATEGIC GROWTH, SAVINGS AND CREDIT COOPERATIVE SOCIETY AND CREDIT UNION INDUSTRY: A GLOBAL OVERVIEW

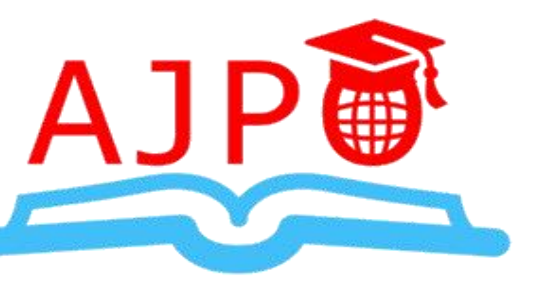




\title{
SUSTAINABLE STRATEGIC GROWTH, SAVINGS AND CREDIT COOPERATIVE SOCIETY AND CREDIT UNION INDUSTRY: A GLOBAL OVERVIEW
}

\author{
$1^{*}$ Ambrose Kipruto Chepkwei \\ PhD Student Jomo Kenyatta University of Agriculture and Technology, Kenya \\ *Author'S E-mail: chepkwei@hotmail.com
}

\begin{abstract}
Purpose: To ascertain the sustainable strategic growth Savings and Credit Cooperative Societies and Credit Unions Industry globally

Methodology: This is a secondary research based on review of existing available literature (from books, conference reports, websites and journals) in the area of Savings and Credit Cooperatives Societies and Credit Unions in various countries globally.

Findings: The study found that number of Savings and Credit Cooperative Societies/Credit Unions in Africa increased by $83.3 \%$, while that of Asia increased by $78.0 \%$ between the periods 2007 and 2016 and the average industry growth for Africa and Asia was 33.2\% and 42.3\% respective. The number of Credit Union growth in Caribbean (-5.6\%), Europe (-23.9\%), Latin America (-4.5\%), North America (-32.6\%) and Oceania (-32.8\%) registered number of Savings and Credit Cooperative Society/Credit Union growth decline between the periods 2007 and 2016. The global aggregate growth in the number of Savings and Credit Cooperative Society/Credit Unions between 2007 and 2016 was $46.0 \%$.

Unique contribution to theory, practice and policy: Considerations for global Savings and Credit Cooperative and Credit Union growth are evaluated on the multiple dimensions of market, region diversity, technological innovation rate, and Savings and Credit Cooperative Society/Credit Union market trends. Growth is the most frequently used corporate strategy. It means increases sales, assets, net profits and a chance to take advantage of the experience curve.
\end{abstract}

Key Words: Growth, Sustainability, Membership, Market share 
Journal of Strategic Management

ISSN 2520-0461(Online)

Vol.3, Issue 1 No.4, pp 37 - 56, 2018

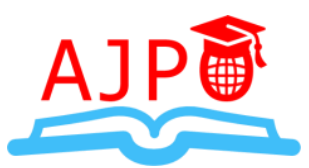

www.ajpojournals.org

\subsection{INTRODUCTION}

\subsection{Background of the Study}

A Savings and Credit Cooperative Society is a cooperative whose objective is to encourage its members to save, thereby creating and accumulating capital, which then is on lend to members at reasonable interest rate (Anania \& Gikuri, 2013). Savings and credits cooperatives commonly known as Savings and Credit Cooperative Societies are financial organization formed by members within the same common bond to mobilize saving and later grant loans to the willing members (Kahuthu, Muturi \& Kiweu, 2015).

Savings and Credit Cooperatives Societies (Savings and Credit Cooperative Societies) play critically an important role in the processes of financial intermediation in the high competitive financial market Savings and Credit Cooperative Societies growth has the effect of bringing multiplier effects thus members are able to obtain economic empowerment and invest some of their savings in real assets (Nkuru, 2015). Savings and Credit Cooperative Societies are voluntary member driven associations, whereby members regularly pool their savings, and later members secure loans which they may utilize for several purposes. Generally the idea of establishment of Savings and Credit Cooperative Society is to encourage savings and make loan available to the members (Bwana \& Mwakujonga, 2013).

Credit Unions on the other hand, are thought of as cooperative credit organizations that provide a variety of financial services to protect the welfare of members (Oteng-Abayie, Owusu-Ansah, \& Amanor, 2016). Individuals further, define a credit union differently. The law on credit unions specifies that a credit union is a credit institution which satisfies its members' economic and social needs has a license for deposit taking for members (Jaseviciene, Tamosiuniene, \& Vidzblyte, 2015). A Credit Union is a special member driven organization, self help financial organization usually organized by and comprise of members of a particular group or organization who consent to save their money together and make credit to members with reasonable interest rates. Normally, members have common bonds either virtue of common workplace, labour union or living in the same community. Membership of a credit unit is open to all who belong to the group, regardless of race, religion, colour or creed (Taiwo, Alege \& Olokoyo, 2016).

Credits unions, banks and credits cooperative banks play an important role in national economy and provide millions of its members to benefits from services in the European Union. Credits unions focus on specific market segmentation usually in the middle or lower. Middle - income people with small and medium - sized business (Dubauskas, 2012). Credits unions also play an important role in the country's regions by providing financial services to residents in the remote areas of Lithuania, Canada offering not only, traditional savings and credit services, but also electronic banking products: internet banking and payment cards (Jaseviciene, Tamosiuniene, \& Vidzblyte, 2015). Credit Unions in Indonesia have well developed and play an important role in supporting its members' economic empowerment (Lingu, 2011).

In the U.S, credit unions also serve traditionally underserved populations and, in the part, experience high customer satisfaction rating. Additionally, bank customer benefits from the presence of credit union through increased competition on rates. Credit Unions are able to pay 
Journal of Strategic Management

ISSN 2520-0461(Online)

Vol.3, Issue 1 No.4, pp 37 - 56, 2018

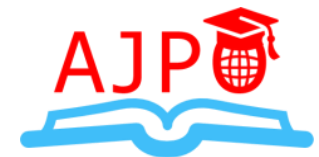

www.ajpojournals.org

higher interest rates on deposits, charge lower interest rate on borrowings, and charge lower and fewer fees than traditional banks (Burke, 2014). One of the most developed movements of credits unions is located in Canada. Since 1955, Lithuanian Canadians have established credits union which played an important role in post war Lithuanian, immigrant's economic life. The structure of the Lithuanian credits unions system closely reflects Desjardins' credits union model, because in this country credits unions started their activities in 1994 with financial support of Canadian International Development Agency (Jaseviciene, Tamosiuniene \& Vidzblyte, 2015).

Credits Unions in the English and Dutch Caribbean were formed in the 1940s through to the mid 1970s, starting in Jamaica in 1942 by Boston - based, Irish - born Jesuit priest, Father John Sullivan, more than 15 years before the first credits union was started in the Ireland itself in 1958 (Edwards, 2014). The first cooperative credits society in the world was founded in Heddesdorf Germany in 1850s. The Heddesdorf credits union was organized in Bavana (Dubauskas, 2012). The Rochdale society of equitable pioneers in 1844 is usually considered the first cooperative enterprise, used as a model for modern cooperative societies, following the Rochdale Principle (Kareem, Arigbabu, Akintaro \& Badmu, 2012).

Credit Unions (CU) cooperatives in West Kalimantan continue to experience significant growth as one of the democracy strength. The use of information technology for service activity in order to keep the solidarity, as members also participated in the growth of the union (Waworuntu, Abdurahman \& Gat, 2017). The concept of microfinance development in Cameroon can be traced back to the $19^{\text {th }}$ Century when money lenders performing the role of new formal institutions. The informal lenders were mostly "Njangi" group and cooperative credits unions (Ofeh \& Jeanne, 2017). Credits unions (C.Us) are thought of as cooperative credits institutions that provide a variety of financial service to safeguard the wellbeing of members. Particularly in Ghana, stiff cooperation offered by the universal banks and other non-financial institutions pose as threats to the sustainability of CUs (Oteng-Abayie, Owusu-Ansah, \& Amanor, 2016). Savings and Credit Cooperative Societies in Ethiopia play a very active role both in rural and urban areas. Their number has increase from 14,437 in2006 to 14,453 in May 2014 showing a compound growth rate of $28 \%$ per year (Tesfamariam, 2015).

The savings and credit cooperative society movement in Africa has evolved from an employeebased where members contribution are collected on a check-off basis by employer from employees salary to non wage-based organization such as farmers. In Africa membership to farmers Savings and Credit Cooperative Societies is, by and large, that rural small scale mixed farming communities. Contributions to farmers Savings and Credit Cooperative Societies are neither guaranteed nor stable which poses growth and sustainability challenges (Bwisa, 2010). Savings and Credit Cooperative Societies develop their products to attract borrowers who use the, money in running various projects in the areas of agriculture, education, construction, and business in Tanzania. When product development is well implemented it drives better outreach performance of Savings and Credit Cooperative Society in Tanzania (Jeje, 2015).

In Kenya $81 \%$ of the population rely on the Savings and Credit Cooperative Societies to access financial services. However the use of Savings and Credit Cooperative Societies by Kenyans as a 
Journal of Strategic Management

ISSN 2520-0461(Online)

Vol.3, Issue 1 No.4, pp 37 - 56, 2018

www.ajpojournals.org

financial services provider has been declining. The Savings and Credit Cooperative Societies are faced with challenges of survival due to decline of members attributed to innovations embraced by banks. Products innovations are crucial to sustain organizations financial performance and raise their competition strengths (Ngure, Maina \& Kariuki, 2017). Savings and Credit Cooperative Societies can be touted to increase the welfare of its members through lowering the cost of investment and growth; this can be achieved through borrowing at lower lending rates and accumulation of savings which imply access to higher levels of credit to members with higher savings. The growth of Savings and Credit Cooperative Societies has been tremendous and thus they are now in the vision blueprint as one of the mobilizers of savings and investment (Kadagi, Wafula \& Ahmed, 2015).

The Savings and Credit Cooperative Societies subsector contribute over 45\% Gross Domestic Product (GDP) in Kenya, while it is estimated that at least one for every two Kenyans directly or indirectly obtain his/her livelihood from these kind of cooperative movement. Tanzania on the other hand cooperative through financing of SMEs contribute about $40 \%$ of the country's GDP and employs $94.7 \%$ of school leavers. The rapid development of savings and credit cooperative society both countries has caused by growth of the private sector (Bwana \& Mwakujonga, 2013). There is a rapid growth in Savings and Credit Cooperative Societies in Kenya and, that cooperatives have not lagged behind in the new scheme of things as Savings and Credit Cooperative Societies have come up with products and services targeting the youth, small businesses and women (Mumanyi, 2014).

\subsection{Statement of the Problem}

Growth in an organization is important since it contribute to the economic prosperity of any entity. Though growth is considered as top strategic priority in organizations, very few achieve it and even fewer have been found to sustain it (Marangu, Lyria \& Rukangu, 2016). The growth and development of credit unions/ Savings and Credit Cooperative Societies and financial cooperatives across the globe impact positive on the poor. In 2016 there were 34 countries in Africa and about 86 worldwide which have embraced the concept of Credit Unions (OtengAbayie, Owusu-Ansah \& Amanor, 2016). Credit Unions have experiences declines in member's satisfaction ratings which could be attributed to the rapid growth of larger Credit Unions that provide less personal service, while on the other hand Credit Unions are dealing with increasing regularly and compliance burdens (Burke, 2014). Small Credit Unions in the United States of America are facing many hardships that are increasing in scope, year over year. The number of Small Credit Unions is declining, and overall Small Credit Unions goes beyond mergers with larger companies (Burke, 2014). Large research on Savings and Credit Cooperative Societies focus more on assessing their performance without looking at key performance drivers such as growth strategies such as market penetration (Jeje, 2015).

\subsection{Main Objective}

To ascertain the sustainable strategic growth Savings and Credit Cooperative Society/Credit Unions Industry globally 
Journal of Strategic Management

ISSN 2520-0461(Online)

Vol.3, Issue 1 No.4, pp 37 - 56, 2018

www.ajpojournals.org

\subsection{LITERATURE REVIEW}

\subsection{Theoretical Review}

\subsubsection{Porter's Five Forces Model}

Porter's five forces model is a strong tool of management used for analyzing the existing industry profitability and appeal by using the outside perspective (Tum, Ombui \& Iravo, 2016). This model has been largely applied in understanding the competitiveness of industries to enable managers shape strategies that would enable them compete favorably (Adi, 2015). Porter recognized the following three generic strategies: cost leadership, differentiation strategy, and focus strategy. The three strategies are supposed to be implemented at the business to build a competitive advantage of the companies (Jaradat, Almomani \& Bataineh, 2017).

State of competition in an industry depends on the five basic forces. Porter's five forces model including bargaining power of customers, bargaining power of suppliers, threats of new comes to the intensity of rivalry between competitions. Join strength of these forces determines the ultimate benefit of potentially in any industry (Tehrani \& Rahmani, 2014). However, quite a number of industries are practicing Michael Porter's five forces model, which is ascertained and broadly employ analytical tool for anatomizing competitive environment (Dhotre \& Raje, 2014). Further, Porter's model is based on the fact that a corporate strategy should rally the opportunities and threats in the organization's external environment (Goral, 2015).

\subsubsection{The BCG Matrix}

The BCG Matrix is considered the oldest, the simplest and the most known matrix of analysis of the portfolio of activities. Strategic decisions concerning resource allocation are essential for a firm to obtain sustainable performance in a competitive environment, and the B.C.G Matrix represents a method allowing for an excellent integration of the financial with the strategic aspects (Duiga, Goitoru, Duiga \& Robescu, 2014).

The continuous development and market introduction of a new business can play an important role in the future performance of companies. The business portfolio analysis represents an analytical approach that views corporation as a set of business units that must be managed in a profitable way. In mid 1960s Bruce Henderson founded Boston consulting group matrix (BCG matrix) which used the experience curve also (a derivative of the learning curve) business could reduce risk and optimize their individual performance by managing specific business units (Ionescu, 2011).

\subsubsection{Market Share}

A study (Jumono, Achsani, Hakim \& Fidaus, 2015) on market concentration, market share and profitability in commercial banks in indonesia revealed that individual market share shows a percentage of control of individual bank in the banking industry. The good market share of deposits will show the conduct of banking in raising total deposits. A study (Fejza \& Asllani, 2013) indicates that every company should set goals or create a strategic plan in order to grow in 
Journal of Strategic Management

ISSN 2520-0461(Online)

Vol.3, Issue 1 No.4, pp 37 - 56, 2018

www.ajpojournals.org

the markets. It is also worth noting that a good number of companies focus in assuring the survival in the market, by increasing their profitability or by growing their market share.

\subsubsection{Savings and Credit Cooperative Society Regulation}

Credit Unions and Savings and Credit Cooperative Societies have registered tremendous growth since the first registration of the first cooperatives legislation deficiency which jeopardize the safety and soundness of Credit Union and Savings and Credit Cooperative Society by restricting their ability to meet members' needs. Jurisdictions that lack sufficient statutory frame work have therefore, hampered the development of Credit Unions and Savings and Credit Cooperative Society. World Council of Credit Unions have created a model law that ensures the continued success and growth of Credit Unions and Savings and Credit Cooperative Societies around the globe (Ryder, 2005).

\subsubsection{Aspects of Savings and Credit Cooperative Society/Credit Union Growth}

\section{Strategic Leadership}

Despite the fact that most Savings and Credit Cooperative Societies in Kenya have strategic plans showing their vision, mission, and their objectives set to be achieved, their service delivery falls below the expectation of the members. Good strategic plans put in place require good strategy implementation which is steered by strategic leadership (Obunga, Marangu, \& Masungo, 2015). It is important for leadership in particular the chief executive communicates with clarity, strategic direction of the organization if it is to achieve its strategic objectives (Olaka, Lewa, \& Kiriri, 2017).

Strategic leaders make and execute business plans to get outcomes. It is the basic function of leadership to organize or streamline the whole organization's working especially the planning and executing strategies (Jabbar \& Hussein, 2017). The ultimate test of any corporate success is the quality of leaders it has helped to nurture and develop over time. The key role of a strategic leader is to encourage and promote innovation by pursuing entrepreneurial opportunities that are important source of growth and opportunities (Eromafuru, 2013). Leadership is one, if not the single most important, factor determining the success or progress of any human endeaviour or organization. Leadership challenges constitute one of the crucial problems confronting organizations (Danquah, Owusu-Bempha, Abbey \& Pokua-Duah, 2015).

Competition in the $21^{\text {st }}$ century's global economy will be complex, challenging, and filled with competitive opportunities and threats. Effective strategic leadership practices can help firms enhance performance while competing in turbulent and unpredictable environments (Ireland \& Hitt, 2005). In the current scenario of competition, leadership provides a competitive edge to organizations. A dynamic leader ensures that things are moving in the right direction and organization is achieving its goals successfully (Masthan, Bashir, Patil \& Shahanaz, 2015). It is construed that a different type of leadership is required for effective strategic decisions are to be made in organizations motivated to become more sustainable while servant leadership, and sustainable leadership approaches provide a sound basis to inform these decisions (Peterlin, Pearse \& Dimovski, 2015). 
Journal of Strategic Management

ISSN 2520-0461(Online)

Vol.3, Issue 1 No.4, pp 37 - 56, 2018

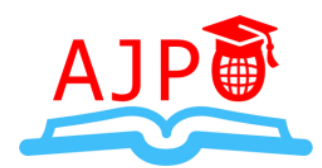

www.ajpojournals.org

\section{Innovation}

Innovation involves acting on the resourceful ideas to make some specific and tangible difference in the area in which the innovation involves the successful execution of creative dreams within the organization (Simiyu, 2013). One of the most dynamic capabilities that front competitive advantage in the organization is innovation capability. The innovation capability is the enormous capacity to offer innovative services and products constantly through the organizational capabilities and capacities (Momeni \& Nielson, 2016).

Technological innovation has become significant prerequisite for organization's survival and growth. This leads to the wonder about the role of technological innovation in the firms' managers' strategies of industry and sector (Khayati, Koubaa \& Zouaoui, 2014). The need for improved efficiency is exerting pressure to the Savings and Credit Cooperative Societies to develop into more competitive entities. The most successful Savings and Credit Cooperative Society will have similarities through real difference will boil down to the ability to use Information Communication Technology (ICT) in executing business ideas that contributes to sustainable growth of Savings and Credit Cooperative Societies (Karugu, Ombado \& Akinyi, 2010).

Product innovations are important in sustaining an organizations' financial performance and raise their competitive strength. In Kenya $81 \%$ of the population rely on the Savings and Credit Cooperative Societies to access financial services. However, the use of Savings and Credit Cooperative Societies by Kenyans as a financial services provider has been declining. The Savings and Credit Cooperative Societies are faced with challenges of survival due to decline of members (Ngure, Maina, \& Kariuki, 2017). However, the successes and rapid growth in Savings and Credit Cooperative Societies reveals a number of basic flaws in the products they offer (Mwangi, Nyachwaya \& Cheruiyot, 2015).

Savings and Credit Cooperative Societies are financial organizations formed by members with same common bond to mobilize savings and later grant loans to the willing members. Prior to 2008 regulatory reforms which became operational in 2010, there was no conscious effort to regulate the subsector prudential because the organizations were not thought to pose risk to the country's financial system. In 2008, the government of Kenya and the Savings and Credit Cooperative Society stakeholders formulated legislation on Savings and Credit Cooperative Society laws (Kahuthu, Muturi \& Kiweu, 2015).

The present business environment is characterized by high level of competition, dynamism and technological sophistication. This is especially challenging to managers since they have to design and implement strategies that can achieve and sustain higher performance level. This has brought companies to new business opportunities for growth and at the same time has exposed them to new competitors (Rotich, Senaji, \& Were, 2017). In a highly competitive environment innovation is the essential key to a firm obtaining a dominants position and gaining higher profits. Hence understanding which strategic innovation management practices lead to success is very important (Kalay \& Lynn, 2015). 
Organizations in all sectors are striving to succeed despite the many challenges they face including issues of globalization, rapid changes, especially changes in technology and increased competition among others. Organizations in the third world are striving to maximize on their major resources to develop and grow their entities by use of their strategic managers (Kyalo, Katuse \& Kirir, 2016).

\subsection{METHODOLOGY}

This article is a secondary research based on review of existing available literature (from books, conference reports, websites and journals) in the area of Savings and Credit Cooperatives Societies and Credit Unions in various countries globally. The researcher explored both the definition of Savings and Credit Cooperative Society and Credit Union as applied in different countries with the objective to comprehend their meaning and application in different countries.

\subsubsection{Global Sustainable Strategic Growth of Savings and Credit Cooperative Societies and Credit Unions}

In the 21st Century, development around the world spread very fast to the globalization movements and information technologies. These changes and developments, forces business to grow and overtop competitors while companies neck to neck nowadays due to number of companies and constant change in attitudes of customer. Therefore businesses need to adapt to their changing environments in order to grow. Savings and Credit Cooperative and Credit Unions need to develop new products and services, find new market places and consequently grow. Growth is, in fact, a part of natural process of business, yet it has become a necessity in today's condition of competition (Durmaz \& Ilhan, 2015). There has been a increasing realization over the years of the significance of cooperatives as critical instruments for socio-economic development across the globe. The contributions of cooperatives include stimulation of economic activities where big businesses cannot profitably operate (Khumalo, 2014). Organization growth can be defined in terms of revenue generation, value addition and expansion in terms of volume of business. It can also be measured in form of market position, quality of product and goodwill of the customers (Gupta, Guhia \& Krishnaswami, 2013).

\subsubsection{Market Penetration as a sustainable growth factor of Savings and Credit Cooperative Societies and Credit Unions Industry}

The penetration rate is calculated by dividing the total number of reported Savings and Credit Cooperative Societies and Credit Union members by economically active population age of between 15 to 64 years old. Penetration as can be seen in Figure 1 indicate that global Savings and Credit Cooperative Societies and Credit Unions had a stagnant growth of penetration between 2007 and 2015, while the years 2009 (7.6\%), 2010 (7.5\%) and 2015 (8.3\%) revealed a drop in market penetration as the year 2016 (13.55\%) recorded the highest global market penetration. 
Figure 1: Savings and Credit Cooperative Society and Credit Union Global Market Penetration

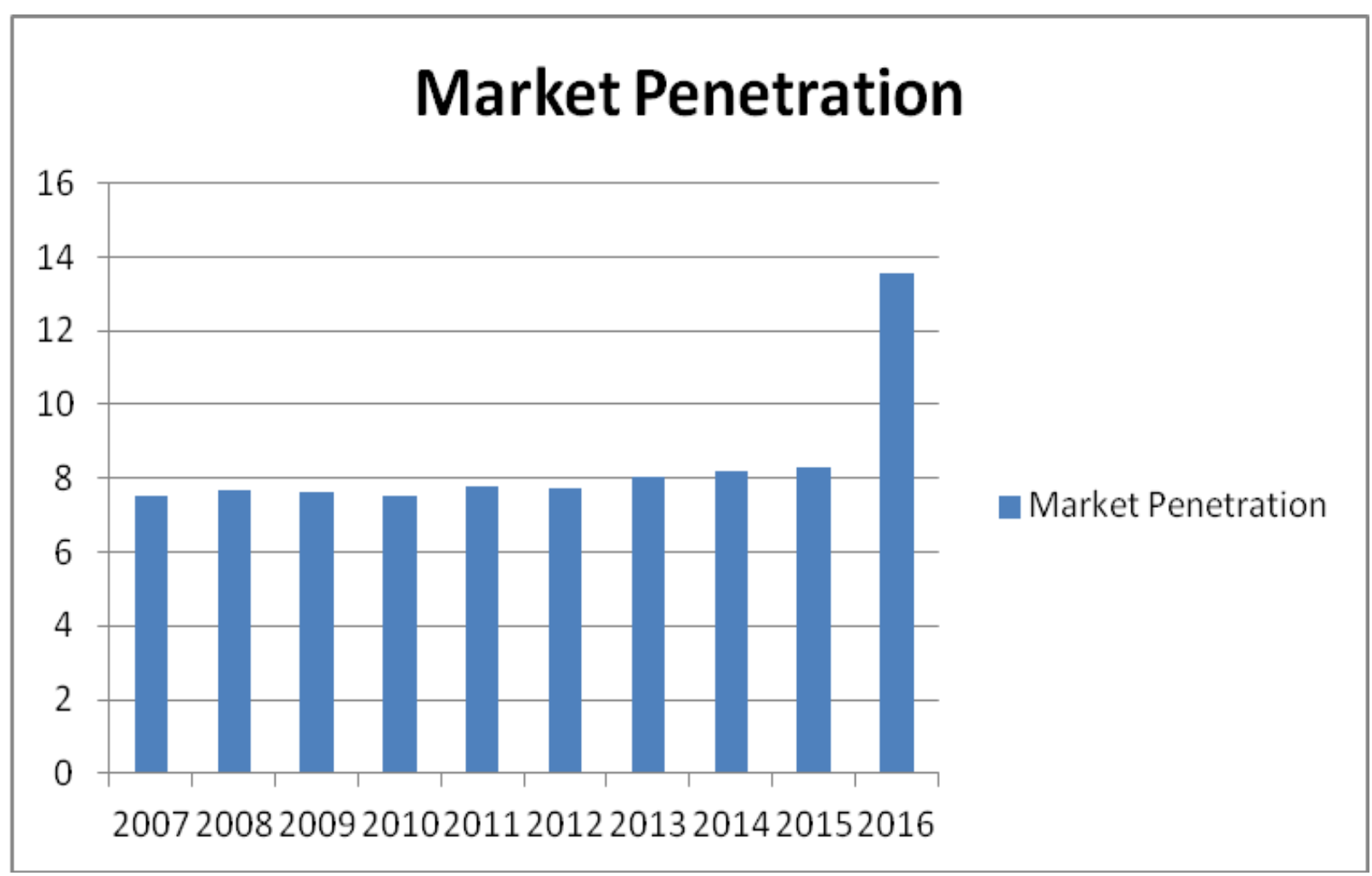

Source: World Council of Credit Unions, 2007-2016 
Journal of Strategic Management

ISSN 2520-0461(Online)

Vol.3, Issue 1 No.4, pp 37 - 56, 2018

www.ajpojournals.org

Table 1: Global Membership Growth as a factor of Savings and Credit Cooperative Society and Credit Union Industry Sustainable Growth (Membership in '000,000')

\begin{tabular}{|c|c|c|c|c|c|c|c|c|c|c|c|c|}
\hline & & 2007 & 2008 & 2009 & 2010 & 2011 & 2012 & 2013 & 2014 & 2015 & 2016 & $\begin{array}{l}\text { Industry } \\
\text { Ave }\end{array}$ \\
\hline Africa & $\begin{array}{l}\mathrm{N} \\
\mathrm{O}\end{array}$ & $\begin{array}{l}15.12 \\
3\end{array}$ & $\begin{array}{l}20.11 \\
7\end{array}$ & $\begin{array}{l}15.59 \\
5\end{array}$ & $\begin{array}{l}17.08 \\
1\end{array}$ & $\begin{array}{l}17.95 \\
1\end{array}$ & $\begin{array}{l}16.02 \\
3\end{array}$ & $\begin{array}{l}17.03 \\
2\end{array}$ & $\begin{array}{l}18.88 \\
1\end{array}$ & $\begin{array}{l}23.24 \\
9\end{array}$ & $\begin{array}{l}23.24 \\
9\end{array}$ & \\
\hline & $\%$ & $\begin{array}{l}8.50 \\
\%\end{array}$ & $\begin{array}{l}10.80 \\
\%\end{array}$ & $\begin{array}{l}8.50 \\
\%\end{array}$ & $\begin{array}{l}9.00 \\
\%\end{array}$ & $\begin{array}{l}9.10 \\
\%\end{array}$ & $\begin{array}{l}8.00 \\
\%\end{array}$ & $\begin{array}{l}8.20 \\
\%\end{array}$ & $\begin{array}{l}8.60 \\
\%\end{array}$ & $\begin{array}{l}8.70 \\
\%\end{array}$ & $9.90 \%$ & $8.90 \%$ \\
\hline Asia & $\begin{array}{l}\mathrm{N} \\
\mathrm{O}\end{array}$ & $\begin{array}{l}33.72 \\
2\end{array}$ & $\begin{array}{l}35.00 \\
3\end{array}$ & $\begin{array}{l}35.91 \\
9 \\
\end{array}$ & $\begin{array}{l}37.80 \\
1\end{array}$ & $\begin{array}{l}39.72 \\
9\end{array}$ & $\begin{array}{l}41.32 \\
3\end{array}$ & $\begin{array}{l}42.01 \\
7 \\
\end{array}$ & $\begin{array}{l}43.86 \\
5\end{array}$ & $\begin{array}{l}45.48 \\
5 \\
\end{array}$ & $\begin{array}{l}50.82 \\
1 \\
\end{array}$ & \\
\hline & $\%$ & $\begin{array}{l}19.00 \\
\%\end{array}$ & $\begin{array}{l}19.30 \\
\%\end{array}$ & $\begin{array}{l}19.50 \\
\%\end{array}$ & $\begin{array}{l}20.10 \\
\%\end{array}$ & $\begin{array}{l}20.20 \\
\%\end{array}$ & $\begin{array}{l}20.60 \\
\%\end{array}$ & $\begin{array}{l}20.20 \\
\%\end{array}$ & $\begin{array}{l}20.10 \\
\%\end{array}$ & $\begin{array}{l}20.40 \\
\%\end{array}$ & $\begin{array}{l}21.60 \\
\%\end{array}$ & $20.10 \%$ \\
\hline $\begin{array}{l}\text { Caribbe } \\
\text { an }\end{array}$ & $\begin{array}{l}\mathrm{N} \\
\mathrm{O}\end{array}$ & 1.866 & 2.33 & 3.023 & 2.805 & 2.946 & 3.056 & 3.182 & 3.437 & 3.597 & 2.258 & \\
\hline & $\%$ & $\begin{array}{l}1.00 \\
\%\end{array}$ & $\begin{array}{l}1.30 \\
\%\end{array}$ & $\begin{array}{l}1.60 \\
\%\end{array}$ & $\begin{array}{l}1.50 \\
\%\end{array}$ & $\begin{array}{l}1.50 \\
\%\end{array}$ & $\begin{array}{l}1.50 \\
\%\end{array}$ & $\begin{array}{l}1.50 \\
\%\end{array}$ & $\begin{array}{l}1.50 \\
\%\end{array}$ & $\begin{array}{l}1.60 \\
\%\end{array}$ & $1.00 \%$ & $1.40 \%$ \\
\hline Europe & $\begin{array}{l}\mathrm{N} \\
\mathrm{O}\end{array}$ & 8.244 & 8.729 & 8.502 & 8.254 & 8.128 & 8.572 & 9.195 & 8.26 & 8.351 & 8.387 & \\
\hline & $\%$ & $\begin{array}{l}4.60 \\
\%\end{array}$ & $\begin{array}{l}4.70 \\
\%\end{array}$ & $\begin{array}{l}4.60 \\
\%\end{array}$ & $\begin{array}{l}4.40 \\
\%\end{array}$ & $\begin{array}{l}4.10 \\
\%\end{array}$ & $\begin{array}{l}4.30 \\
\%\end{array}$ & $\begin{array}{l}4.40 \\
\%\end{array}$ & $\begin{array}{l}3.70 \\
\%\end{array}$ & $\begin{array}{l}3.70 \\
\%\end{array}$ & $3.60 \%$ & $4.20 \%$ \\
\hline $\begin{array}{l}\text { L/Ameri } \\
\mathrm{ca}\end{array}$ & $\begin{array}{l}\mathrm{N} \\
\mathrm{O}\end{array}$ & $\begin{array}{l}15.14 \\
1\end{array}$ & 14.92 & $\begin{array}{l}14.98 \\
2\end{array}$ & $\begin{array}{l}15.67 \\
8\end{array}$ & $\begin{array}{l}18.08 \\
6\end{array}$ & $\begin{array}{l}20.83 \\
5\end{array}$ & $\begin{array}{l}23.96 \\
8\end{array}$ & $\begin{array}{l}27.35 \\
1\end{array}$ & $\begin{array}{l}27.31 \\
1\end{array}$ & $\begin{array}{l}27.90 \\
8\end{array}$ & \\
\hline & $\%$ & $\begin{array}{l}8.50 \\
\%\end{array}$ & $\begin{array}{l}8.00 \\
\%\end{array}$ & $\begin{array}{l}8.10 \\
\%\end{array}$ & $\begin{array}{l}8.30 \\
\%\end{array}$ & $\begin{array}{l}9.20 \\
\%\end{array}$ & $\begin{array}{l}10.40 \\
\%\end{array}$ & $\begin{array}{l}11.50 \\
\%\end{array}$ & $\begin{array}{l}12.60 \\
\%\end{array}$ & $\begin{array}{l}12.30 \\
\%\end{array}$ & $\begin{array}{l}11.80 \\
\%\end{array}$ & $10.00 \%$ \\
\hline $\begin{array}{l}\text { N/Ameri } \\
\mathrm{ca}\end{array}$ & $\begin{array}{l}\mathrm{N} \\
\mathrm{O}\end{array}$ & $\begin{array}{l}99.37 \\
1 \\
\end{array}$ & $\begin{array}{l}100.8 \\
2\end{array}$ & $\begin{array}{l}101.9 \\
8\end{array}$ & $\begin{array}{l}102.5 \\
2\end{array}$ & $\begin{array}{l}104.5 \\
4 \\
\end{array}$ & $\begin{array}{l}105.2 \\
9\end{array}$ & $\begin{array}{l}107.6 \\
1\end{array}$ & $\begin{array}{l}110.6 \\
4\end{array}$ & $\begin{array}{l}114.0 \\
6\end{array}$ & $\begin{array}{l}118.4 \\
6\end{array}$ & \\
\hline & $\%$ & $\begin{array}{l}56.00 \\
\%\end{array}$ & $\begin{array}{l}54.20 \\
\%\end{array}$ & $\begin{array}{l}55.40 \\
\%\end{array}$ & $\begin{array}{l}54.50 \\
\%\end{array}$ & $\begin{array}{l}53.20 \\
\%\end{array}$ & $\begin{array}{l}52.60 \\
\%\end{array}$ & $\begin{array}{l}51.80 \\
\%\end{array}$ & $\begin{array}{l}50.90 \\
\%\end{array}$ & $\begin{array}{l}51.20 \\
\%\end{array}$ & $\begin{array}{l}50.20 \\
\%\end{array}$ & $53.00 \%$ \\
\hline Oceania & $\begin{array}{l}\mathrm{N} \\
\mathrm{O}\end{array}$ & 3.915 & 3.885 & 3.92 & 3.845 & 5.12 & 5.147 & 4.935 & 4.945 & 4.558 & 4.679 & \\
\hline & $\%$ & $\begin{array}{l}2.20 \\
\%\end{array}$ & $\begin{array}{l}2.00 \\
\%\end{array}$ & $\begin{array}{l}2.10 \\
\%\end{array}$ & $\begin{array}{l}2.00 \\
\%\end{array}$ & $\begin{array}{l}2.60 \\
\%\end{array}$ & $\begin{array}{l}2.60 \\
\%\end{array}$ & $\begin{array}{l}2.30 \\
\%\end{array}$ & $\begin{array}{l}2.30 \\
\%\end{array}$ & $\begin{array}{l}2.00 \\
\%\end{array}$ & $2.00 \%$ & $2.20 \%$ \\
\hline Total & & $\begin{array}{l}177.3 \\
7\end{array}$ & 185.8 & $\begin{array}{l}183.9 \\
2\end{array}$ & $\begin{array}{l}187.9 \\
9\end{array}$ & 196.5 & $\begin{array}{l}200.2 \\
4\end{array}$ & $\begin{array}{l}207.9 \\
4\end{array}$ & $\begin{array}{l}217.3 \\
7\end{array}$ & 222.8 & $\begin{array}{l}235.7 \\
62\end{array}$ & \\
\hline
\end{tabular}

Source: World Council of Credit Unions, 2007-2016

The membership growth as observed on Table 1 shows that there is global sustainable growth of Savings and Credit Cooperative Societies and Credit Union membership. North America (53.0\%) is the industry leader of global membership growth and Asia (20.1\%) follows while Latin America (10.0\%) and Africa (8.9\%) are the next global upcoming membership growth players in Savings and Credit Cooperative Societies and Credit Union industry. Caribbean registered the lowest global membership growth in Credit Unions. Credit Unions globally should be able to bench mark North America Credit Unions. The highest global Savings and Credit Cooperative Society and credit Union membership growth with the four leading Savings and Credit Cooperative Societies and Credit Unions: North America 2007(56.0\%); Asia 
Journal of Strategic Management

ISSN 2520-0461(Online)

Vol.3, Issue 1 No.4, pp 37 - 56, 2018

www.ajpojournals.org

2016(21.6\%); Latin America 2014 (12.6); and Africa 2008 (10.8\%). Therefore, as North America leads in global Savings and Credit Cooperative Society and Credit Union membership growth it registered the highest growth a long time ago as compared with Asia and Latin America which did most recently.

\subsubsection{Growth in the number of Savings and Credit Cooperative Societies/Credit Unions as a factor of Sustainable Global Growth of Industry}

Credit Unions as microfinance institutions have some peculiar challenges in the changing world due to nature and current economic trends. Consumers do not realize that membership of a credit union/SAVINGS AND CREDIT COOPERATIVE SOCIETY is possible for virtually everyone. People think that they have to be in certain industry or work for specific employer to have access to a credit (Amegashie-Viglo, 2014).

Table 2: Global Growth in the number of SACCOs/Credit Unions

\begin{tabular}{|l|l|l|l|l|l|l|l|l|l|l|l|}
\hline & & 2007 & 2008 & 2009 & 2010 & 2011 & 2012 & 2013 & 2014 & 2015 & 2016 \\
\hline Africa & No & 11849 & 18220 & 14404 & 17561 & 18,221 & 20,831 & 22,385 & 20,422 & 21,040 & 21,724 \\
\hline & $\%$ & $25.1 \%$ & $33.9 \%$ & $29.1 \%$ & $33.2 \%$ & $32.6 \%$ & $37.2 \%$ & $39.3 \%$ & $35.5 \%$ & $34.7 \%$ & $31.5 \%$ \\
\hline Asia & No & 20199 & 21076 & 21333 & 22162 & 19,798 & 21,934 & 21,570 & 24,552 & 27,492 & 35,957 \\
\hline & $\%$ & $42.8 \%$ & $39.3 \%$ & $43.2 \%$ & $41.9 \%$ & $38.8 \%$ & $39.2 \%$ & $37.9 \%$ & $42.7 \%$ & $45.3 \%$ & $52.2 \%$ \\
\hline Caribbean & No & 317 & 482 & 556 & 447 & 433 & 412 & 398 & 391 & 386 & 299 \\
\hline & $\%$ & $0.7 \%$ & $0.9 \%$ & $1.1 \%$ & $0.8 \%$ & $0.8 \%$ & $0.7 \%$ & $0.7 \%$ & $0.7 \%$ & $0.6 \%$ & $0.4 \%$ \\
\hline Europe & No & 2671 & 2569 & 2418 & 2394 & 2,321 & 2,320 & 2,390 & 2,319 & 2,220 & 2,033 \\
\hline & $\%$ & $5.7 \%$ & $4.8 \%$ & $4.9 \%$ & $4.5 \%$ & $4.5 \%$ & $4.1 \%$ & $4.2 \%$ & $4.0 \%$ & $3.7 \%$ & $3.0 \%$ \\
\hline $\begin{array}{l}\text { Latin } \\
\text { America }\end{array}$ & No & 2504 & 2083 & 1784 & 1745 & 1,750 & 2,446 & 2,540 & 2,491 & 2,513 & 2,391 \\
\hline & $\%$ & $5.3 \%$ & $3.9 \%$ & $3.6 \%$ & $3.2 \%$ & $3.4 \%$ & $4.4 \%$ & $4.5 \%$ & $4.3 \%$ & $4.1 \%$ & $3.5 \%$ \\
\hline $\begin{array}{l}\text { North } \\
\text { America }\end{array}$ & No & 9328 & 8977 & 8653 & 8368 & 8,164 & 7,731 & 7,405 & 7,093 & 6,795 & 6,280 \\
\hline & $\%$ & $19.8 \%$ & $16.7 \%$ & $17.5 \%$ & $15.8 \%$ & $16.0 \%$ & $13.8 \%$ & $13.0 \%$ & $12.3 \%$ & $11.2 \%$ & $9.1 \%$ \\
\hline Oceania & No & 295 & 282 & 282 & 268 & 326 & 278 & 216 & 213 & 199 & 198 \\
\hline & & $0.6 \%$ & $0.5 \%$ & $0.5 \%$ & $0.5 \%$ & $0.6 \%$ & $0.5 \%$ & $0.4 \%$ & $0.4 \%$ & $0.3 \%$ & $0.3 \%$ \\
\hline Total & & $\mathbf{4 7 , 1 6 3}$ & $\mathbf{5 3 , 6 8 9}$ & $\mathbf{4 9 , 4 3 0}$ & $\mathbf{5 2 , 9 4 5}$ & $\mathbf{5 1 , 0 1 3}$ & $\mathbf{5 5 , 9 5 2}$ & $\mathbf{5 6 , 9 0 4}$ & $\mathbf{5 7 , 4 8 1}$ & $\mathbf{6 0 , 6 4 5}$ & $\mathbf{6 8 , 8 8 2}$ \\
\hline
\end{tabular}

Source: World Council of Credit Unions Statistical Report 2007- 2016

As can be noted from the above table 2, the number of Savings and Credit Cooperative Societies/Credit Unions in Africa increased by $83.3 \%$, while that of Asia increased by $78.0 \%$ between the periods 2007 and 2016 and the average industry growth for Africa and Asia was $33.2 \%$ and $42.3 \%$ respective. The number of Credit Union growth in Caribbean (-5.6\%), Europe (-23.9\%), Latin America (-4.5\%), North America (-32.6\%) and Oceania (-32.8\%) registered number of Savings and Credit Cooperative Society/Credit Union growth decline between the periods 2007 and 2016. The global aggregate growth in the number of Savings and Credit Cooperative Society/Credit Unions between 2007 and 2016 was 46.0\%. 
Journal of Strategic Management

ISSN 2520-0461(Online)

Vol.3, Issue 1 No.4, pp 37 - 56, 2018

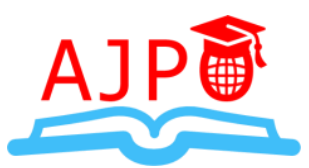

www.ajpojournals.org

\subsection{RECOMMENDATION AND CONCLUSION}

Given the competitive environment of the Savings and Credit Cooperative Societies clients demand, it is important for Savings and Credit Cooperative Societies to utilize accepted models for effective resource allocation to different strategic business units (Debrecht \& Levas, 2014). Considerations for global growth may be evaluated on the multiple dimensions of market and region diversity, relative competitiveness in each region, technological innovation rate, and Savings and Credit Cooperative Society market trends (Godiwalla, 2016). Growth is the most frequently used corporate strategy. It means increases sales, assets, net profits and a chance to take advantage of the experience curve (Absanto \& Nnko, 2013).

In today's fast changing economic situation, every Savings and Credit Cooperative Society is trying to assess its performances regularly. In order to survive Savings and Credit Cooperative Societies and Credit Unions are taking steps to expand by accessing new markets; making product and price more attractive; satisfying customers; and developing new strategies (Anna, 2015). In every economy, both the developed and developing world, various avenues exist for addressing financial needs or challenges of citizens and households; one of which is through the operation of a credit union scheme that plays a major role in providing support for the financially excluded in society (Amegashie-Viglo, 2014). Strategic Leadership remains the art of corporate organization. It is the most important factor in the survival and growth of the firm. The continuing existence of the firm depends on the leadership of the firm (Sunday, Adekunle \& Oluitan, 2014).

Small and Medium-sized enterprises (SMEs) including Savings and Credit Cooperative Societies, play a pivotal role as engines of growth in many economies. These SMEs are responsible for driving entrepreneurship, innovation, and competition in all sectors of an economy. Market penetration growth strategy allows a firm to penetrate more deeply into its existing market and increase its share of that market (Uko \& Ayatse, 2014). A business utilizes market penetration strategy to attempt to penetrate in an existing market. Market penetration involves increased sales turnover of products in a market that is already in existence (Wainaina \& Oloko, 2016). Strategies must be aligned to innovation capabilities to foster business model, since it mediates between the technology and economic platform domain (Rodrigues, Maccari \& Lenzi, 2012).

Credit Unions/Savings and Credit Cooperative Societies expect prospective members to meet the requirement of being a member of a certain group or class within particular community, contributing a certain amount of money periodically or being of a particular character. The strict bond requirements do not auger well for the growth of Credit Union/Savings and Credit Cooperative Society (Anku-Tsede \& Amankwaa, 2015). Credit Unions/Savings and Credit Cooperative Societies in an urban set up are founded by regular income earner's who have common bond, and whose employers are ready to effect check-off system from monthly contributions and loan repayments from members. Whereas, most Credit Unions/Savings and Credit Cooperative Societies in the rural set up are community based, their main activity is agriculture and small scale businesses (Mumanyi, 2014). 
Nowadays due to competition Credit Unions/Savings and Credit Cooperative Society and various financial including banks are offering micro credits to customer within a short period of time and have very simple requirements that make customers qualify for loans. The challenge here comes as sustainability of the Credit Union/Savings and Credit Cooperative Societies may be at threat. The members who feel that Savings and Credit Cooperative Societies cannot provide them with the services they want (Anania \& Gikuri, 2013). Savings and Credit Cooperative Societies compete in a dynamic business competitive environment that affects their performance. Therefore, Savings and Credit Cooperative Societies must formulate and implement sound competitive strategies in order to compete effectively, to provide goods and services that cannot be easily imitated by competitors (Sagwa \& Kembu, 2016). Competition is the ability of the firm to increase its market share of its products or services, which is always under threat by other firms in the same industry. Competition is important because good competition brings about quality goods and services, innovations and efficiency in provision of goods and services (Nkuru, 2015).

Savings and Credit Cooperative Societies are recognized by law and cooperative society's regulations. Some countries in Europe, United States of America, and other global regions simply call them credit unions others popular people's banks or Cajas especially in Europe (Tumwine, Mbabazize, \& Shukla, 2015). Savings and Credit Cooperatives and Credit Unions have played a significant role towards achieving the growth and poverty reduction strategy in most countries, through the promotion of income generating activities and improved access to nearby banking activities in urban or rural households (Tesfamariam, 2015).

\section{REFERENCES}

Absanto, G., \& Nnko, E. (2013). Analysis of business growth strategies and their contribution to business growth. International Journal of Economics, Commerce and Management , 1 (1), $1-14$.

Adi, B. (2015). An Evaluation of the nigerian telecommunication industry completeness: Application of Porter's Five Forces Model. World Journal of Social Sciences , 5 (3), 1536.

Amegashie-Viglo, S. (2014). Operation of credit union scheme as a strategy for meeting the financial expectations of the marginalized: The case of Ho Municipality Credit Unions in Ghana. Research Journal of Finance and Accounting , 5 (14), 20-33.

Anania, P., \& Gikuri, A. (2013). Savings and Credit Cooperative Societies and Members' Expectations: Factors AFFECTING SAVINGS AND CREDIT COOPERATIVE SOCIETIES CAPACITY TO MEET MEMBERS' EXPECTATIONS. Cooperative Research Workshop (pp. 1-14). Moshi: Moshi Cooperative University. 
Anku-Tsede, O., \& Amankwaa, A. (2015). The Institutional and Regulatory Framework of Cooperatives in Ghana: Implications for Credit Unions. International Journal of Cooperative Studies , 4 (2), 18-26.

Anna, A. (2015). Strategic management tools and techniques and organizational performance: findings from Czech Republic. Journal of Competitiveness , 7 (3), 19-36.

Burke, M. (2014). Analysis of small credit unions trends and opportunities for accountants. Accounting and Finance Research , 3 (4), 15-23.

Bwana, K., \& Mwakujonga, J. (2013). Issues in Savings and Credit Cooperative Societies Development in Kenya and Tanzania: Historical Perspectives. Developing Country Studies , 3 (5), 114-121.

Bwisa, H. (2010). An Entrepreneurial Approach to Use of ICT for the Growth of Africa's Cooperative Movement: The Case of the Mobile Phone. 11th SACCA Congress (pp. 120). Swaziland: ACCOSCA.

Danquah, E., Owusu-Bempha, G., Abbey, W., \& Pokua-Duah, G. (2015). Examining the Leadership Styles within Ghana Link Network Services. European Journal of Business and Management , 7 (12), 25-30.

Debrecht, D., \& Levas, M. (2014). Using Boston Consulting Group Portfolio Matrix to Analyze Management of a Business Undergraduate Student Program at Leberal Arts University. Journal of Higher Education Theory and Practice , 14 (3), 65-69.

Dhotre, M., \& Raje, P. (2014). Application of Porter's Five Forces Model in the BPM Industry. MERC Global's International Journal of Management , 2 (2), 51-65.

Dubauskas, G. (2012). Sustainable Growth of Financial Sector: The Case of Credit Unions. Journal of Security and Sustainablility Issues , 1 (3), 159-166.

Duiga, A., Goitoru, G., Duiga, M., \& Robescu, O. (2014). The Rise and Fall of B.C.G Model. Management Challenges for Sustainable Development (pp. 143-152). Bucharest, Romania: 8th International Management Conference.

Durmaz, Y., \& Ilhan, A. (2015). Growth Strategies in Business and A Theoretical Approach. International Journal of Business and Management , 10 (4), 210-214.

Edwards, M. (2014). The Next Chapter of Growth in the Caribbean Credit Union Movement. Quebec International Submit of Cooperatives, (pp. 367-383). Quebec. 
Eromafuru, E. (2013). Building and sustaining supportive organizational culture through innovative and strategic leadership. International Journal of Humanities and Social Science, 3 (11), 130-137.

Fejza, E., \& Asllani, A. (2013). The importance of marketing in helping companies with their growth strategies: The Case of Food Industry in Kosovo. European Scientific Journal , 9 (16), 326-335.

Godiwalla, Y. (2016). Formulating an international growth strategy: Considerations for MNC Decision Making Process. International Journal of Social Science Studies , 4 (7), 76-81.

Goral, R. (2015). Competitive analysis of the hotel industry in Konya by Using Porter's Five Forces Model. European Journal of Economics and Business Studies , 3 (1), 106-115.

Gupta, P., Guhia, S., \& Krishnaswami, S. (2013). Firm growth and its determinants. Journal of Innovation and Entrepreneurship, 15, 1-14.

Intermediation in the Improvement of the Welfare of Members: A Case Study of Fundilima Savings and Credit Cooperative Society. International Journal of Scientific and Research Publication , 5 (6), 756-768.

Ionescu, F. (2011). Boston Consulting Group II - A Business Portfolio Analysis Matrix. International Journal of Economic Practices and Theories , 1 (2), 65-70.

Ireland, R., \& Hitt, M. (2005). Achieving and maintaining strategic competitiveness in the 21st century: The role of strategic leadership. Academy of Management Executive , 19 (4), 6377.

Jabbar, A., \& Hussein, A. (2017). The role of leadership in strategic management. International Journal of Research - Granthaalayah , 5 (5), 99-106.

Jaradat, A., Almomani, S., \& Bataineh, M. (2013). The impact of porter model's five compentency powers on selecting business strategy: An Emphirical Study on Jordanian Food Industrial Companies. Interdisciplinary Journal of Contemporary Research Business , 5 (5), 457-470.

Jaseviciene, F., Tamosiuniene, R., \& Vidzblyte, S. (2015). credit union's thoerectical aspects and performance analysis. KSI Transactional on Knowledge Society , 3 (1), 28-34.

Jeje, K. (2015). Intensive growth strategies and outreach performance of Tanzania-based savings and credit cooperative. International Journal of Business and Management , 10 (1), 124135. 
Jumono, S., Achsani, N., Hakim, B., \& Fidaus, M. (2015). Market Concentration, Market Share, and Profitability ( Study at Indonesiaan Commercial Banking in the Period 2001 -2012). Asian Social Science, 11(27), 19-27.

Kadagi, N., Wafula, M., \& Ahmed, A. (2015). Role Played by Savings and Credit Cooperative Societies in Financial

Kahuthu, D., Muturi, W., \& Kiweu, M. (2015). The impact of core capital and membership growth on financial performance of Deposit Taking Savings and Credit Cooperatives in Kenya. European Journal of Business and Management , 3 (5), 114-121.

Kalay, F., \& Lynn, G. (2015). The Impact of strategic innovation management practices on firm innovation performance. Research Journal of Business Management , 2 (3), 412-429.

Kareem, R., Arigbabu, Y., Akintaro, J., \& Badmu, M. (2012). The impact of cooperative society on capital formation: A Case Study of Temidere Cooperative and Thrift Society, JjebuOde, Ogun State, Nigeria. Global Journal of Science Frontier Research Agriculture and Veterinary Sciences , 12 (11), 16-28.

Karugu, C., Ombado, G., \& Akinyi, S. (2010). The youth factor is critical to sustainable growth and development of savings and credit cooperative societies in Africa. 11th SACCA Conference (pp. 1-12). Swaziland: ACCOSCA.

Khayati, L., Koubaa, M., \& Zouaoui, M. (2014). Technological innovation and business strategy: A Cognitive Mapping Approach. International Journal of Research in Management \& Business Studies , 1 (1), 130-138.

Khumalo, P. (2014). Improving the contribution of cooperatives as vehicles for local economic development in South Africa. Africa Studies Quarterly, 14 (4), 62-79.

Kyalo, J., Katuse, P., \& Kirir, P. (2016). Effects of organization leadership on strategy implementation in Kenya's Toursm Industry: Case of Kenya Government Toursm Agencies. The International Journal of Business and Management , 4 (6), 36-46.

Lingu, A. (2011). The influencial factors towards credit union members ( Studies in CU Network Boards of CU in Kalimantan). Journal of Economics, Business and Accountancy Ventura , $14(1), 45-58$.

Marangu, M., Lyria, R., \& Rukangu, S. (2016). Influence of human resource practices on growth of Savings and Credit Cooperative Society Socities in Meru County, Kenya. International Journal of Science and Research , 5 (11), 31-37. 
Masthan, D., Bashir, N., Patil, J., \& Shahanaz, J. (2015). Leadership development practices in service industry: An Emphirical Analysis. European Journal of Business and Management , 7 (9), 123-128.

Momeni, M., \& Nielson, S. (2016). Impact of personnel capabilities on organizational innovation capabililty. Journal of Management and Innovation , 2 (2), 1-24.

Mumanyi, E. (2014). Challenges and opportunities facing savings and Credit Cooperative Societies in Current Devolved System of Government of Kenya: A Case Study of Mombasa County. International Journal of Social Sciences and Entrepreneurship , 1 (9), 288-314.

Mwangi, J., Nyachwaya, Z., \& Cheruiyot, R. (2015). Effect of corporate governance practices on financial performance of savings and credit cooperative societies in Kericho Municipality. IOSR Journal of Economics and Finance , 6 (3), 57-75.

Ngure, K., Maina, K., \& Kariuki, S. (2017). Product innovation and financial performance of Savings and Credit Cooperative Societies in Kirinyaga County, Kenya. International Academic Journal of Human Resource and Business Administration , 2 (3), 166-178.

Nkuru, F. (2015). Factors affecting growth of Savings and Credit Cooperative Societies within the Agricultural Sector in Kenya: A case of Meru Farmers SAVINGS AND CREDIT COOPERATIVE SOCIETY. Global Journal of Commerce \& Management Perspective , $4(1), 34-45$.

Obunga, C., Marangu, W., \& Masungo, T. (2015). Strategic leadership and performance of Savings and Credit Cooperative Societies in Kakamega County, Kenya. European Journal of Business and Management , 7 (13), 65-75.

Ofeh, M., \& Jeanne, Z. (2017). Financial Performance of Microfinance Institutions in Cameroon: Case of CamCCUL Ltd. International Journal of Economics and Finance , 4, 207-224.

Olaka, H., Lewa, P., \& Kiriri, P. (2017). Strategic Leadership and Strategy Implementation in Commercial Banks in Kenya. Journal of Strategic Management , 2 (1), 70-94.

Oteng-Abayie, E., Owusu-Ansah, B., \& Amanor, K. (2016). Techinical Effeciency of Credit Unions in Ghana. Journal of Finance and Economics , 4 (3), 88-96.

Peterlin, J., Pearse, N., \& Dimovski, V. (2015). Strategic Decision making for Organizational Sustainability: The Implications of Servant Leadership and Sustainable Leadership Approaches. Economic and Business Review , 17 (3), 273-290.

Rodrigues, L., Maccari, E., \& Lenzi, F. (2012). Innovation Strategy for Business to Business Market Penetration. International Business Research , 5 (2), 137-149. 
Rotich, S., Senaji, T., \& Were, E. (2017). Factors influencing strategy implementation among Savings and Credit Cooperative Societies in Kenya: A Survey of Deposit Taking Savings and Credit Cooperative Societies in Nairobi County, Kenya. International Journal of Business and Finance , 1 (22), 369-390.

Ryder, N. (2005). The Regulation of Credit Unions: A Comparative Analysis between the USA and Great Britain. Journal of Banking Regulation, 6(3), 261-273.

Sagwa, E., \& Kembu, A. (2016). Effects of Competitive Strategy on the performance of deposit Taking Savings and Credit Cooperative Societies in Nairobi County, Kenya. European Journal of Business Management , 8 (8), 30-37.

Simiyu, F. (2013). Effects of Innovation Strategies on performance of commercial banks in Kenya. International Journal of Social Sciences and Entrepreneuship , 1 (3), 198-198.

Sunday, K., Adekunle, I., \& Oluitan, R. (2014). Organization Survival: The Effects ofLeadership Skill and Strategy. Science Journal of Business Management , 2 (2), 44-49.

Taiwo, J., Alege, P., \& Olokoyo, F. (2016). Microfinancing and Microenterprise Growth in Nigeria. Lagos Journal of Banking \& Economic Issues , 3 (1), 87-119.

Tehrani, M., \& Rahmani, F. (2014). Evaluation Strategy Michael Porter's Five Forces Model of the Competitive Environment. American Journal of Engineering Research , 03 (05), 8085.

Tesfamariam, K. (2015). Savings and Credit Cooperatives in Ethiopia: Development and Challenges. Journal of Economic and Sustainable Development , 6 (5), 140-146.

Tum, B., Ombui, A., \& Iravo, M. (2016). Influence of Porter's Five Forces Model Strategy on Performance of Selected Telecommunication Companies in Kenya. International Journal of Scientific and Research Publications , 6 (10), 558-568.

Tumwine, F., Mbabazize, M., \& Shukla, J. (2015). Savings and Credit Cooperative Societies(Savings and Credit Cooperative Societies) Services' Terms and Members' Economic Development in Rwanda. International Journal of Community and Cooperative Studies , 3 (2), 1-6.

Uko, J., \& Ayatse, F. (2014). Market Penetration as Growth Strategy for Small and Medium Sized Enterprises in Nigeria. Management and Administrative Sciences Review , 3 (1), 823.

Wainaina, G., \& Oloko, M. (2016). Market Penetration Strategies and Organization Growth: A Case of Soft Drink Sector in Kenya. International Journal of Management and Commerce Innovations , 3 (2), 219-227. 
Journal of Strategic Management

ISSN 2520-0461(Online)

Vol.3, Issue 1 No.4, pp 37 - 56, 2018

www.ajpojournals.org

Waworuntu, S., Abdurahman, E., \& Gat, E. (2017). Contribution of Information Technology through, Consumer Engagement to Improve Market Growth of Credit Unions. 5th International Conference on Cyber and IT Service Management, (pp. 1-6). Denpasar.

WOCCU. (2007-2016). Statistical Report. Washingdon, DC: World Council of Credit Unions. 